\title{
Trace Metals Levels in African Giant Land Snails (Achatina achatina) from Selected Local Government Areas in Akwa Ibom State, Nigeria
}

\author{
Ishaq S. Eneji*, Raymond A. Wuana, Utibe J. Akpan \\ Department of Chemistry, College of Science, Federal University of Agriculture Makurdi, Makurdi, Nigeria \\ Email: "ishaqeneji@gmail.com
}

Received 9 March 2016; accepted 26 March 2016; published 29 March 2016

Copyright (C) 2016 by authors and OALib.

This work is licensed under the Creative Commons Attribution International License (CC BY). http://creativecommons.org/licenses/by/4.0/

(c) (i) Open Access

\begin{abstract}
Trace metals (As, $\mathrm{Cd}, \mathrm{Cr}, \mathrm{Hg}, \mathrm{Pb}$ and $\mathrm{Se}$ ) in African giant land snails from selected Local Government Areas (LGA) in Akwa Ibom State of Nigeria were analysed using atomic absorption spectrophotometric (AAS) technique. Results showed that the mean levels of $\mathrm{Cr}(399 \pm 195 \mathrm{mg} / \mathrm{kg})$ and Se $(51.6 \pm 31.3 \mathrm{mg} / \mathrm{kg})$ were significantly higher $(\mathrm{P}<0.05)$ than the maximum recommended limits of $1.0 \mathrm{mg} / \mathrm{kg}$ and $3.5 \mathrm{mg} / \mathrm{kg}$ for $\mathrm{Cr}$ and Se, respectively. As, Cd and Pb levels were beyond the detection limit in the snail samples obtained from Essien Udim, Ikot Ekpene and Etim Ekpo LGA. Similarly, $\mathrm{Hg}$ level was beyond the detection limit in all samples investigated. The general pattern of trace metals levels was in the order: $\mathrm{Cr}>\mathrm{Se}>\mathrm{Pb}>\mathrm{Cd}>\mathrm{As}>\mathrm{Hg}$. The results showed that As and $\mathrm{Hg}$ fell within their permissible safe levels; but $\mathrm{Cd}, \mathrm{Cr}, \mathrm{Pb}$ and Se were significantly above safe levels for human consumption. The high concentration of trace metals in the snail samples may be related to anthropogenic activities taking place in the areas studied.
\end{abstract}

\section{Keywords}

Trace Metals, Achatina achatina, Bioaccumulation, Akwa Ibom, Anthropogenic, Atomic Absorption Spectrophotometry

Subject Areas: Agricultural Science

\section{Introduction}

Trace metals are natural components of the earth crust and cannot be degraded. The systematic release of these ${ }^{*}$ Corresponding author.

How to cite this paper: Eneji, I.S., Wuana, R.A. and Akpan, U.J. (2016) Trace Metals Levels in African Giant Land Snails (Achatina achatina) from Selected Local Government Areas in Akwa Ibom State, Nigeria. Open Access Library Journal, 3: e2244. http://dx.doi.org/10.4236/oalib.1102244 
metals from both natural sources and human activities into the environment is of great concern [1]. Some of these metals pose a risk to environmental and human health via the food chain and other sources of human exposure as a result of their toxicity [2]. These contaminants are accumulated by living organisms in their bodies and subsequently biomagnified as they pass from one trophic level to the next. Contamination of terrestrial environment by trace elements leads to an increasing uptake of metals by soil invertebrates, including land snails. Since man is at the top of food chain, he is vulnerable to metal pollution [3].

The African giant land snail feeds on the debris from the soil surface which may be contaminated with trace metals which may have accumulated to harmful levels. Snails are abundant in many terrestrial and aquatic ecosystems, being easily available for collection. They are highly tolerant to many pollutants and exhibit high accumulations of them, particularly heavy metals [4]. Trace metals such as $\mathrm{Cu}, \mathrm{Zn}, \mathrm{Pb}, \mathrm{Hg}, \mathrm{Al}, \mathrm{Cr}$ and $\mathrm{Cd}$ are normal constituents of marine environment, and traces are always found in marine organisms [5].

Metal uptake through food is regarded as the main route of contamination in terrestrial invertebrates [4]. Metal uptake via epithelial tissues cannot be ignored because terrestrial pulmonates spend their entire lives on or in the upper soil horizons and therefore, the snail tegument comes frequently in direct contact with polluted substrates [6]. However, in natural environments, metal uptake is a cumulative process that occurs via mixed air, soil and food exposures [7]. Most ingested metals are metabolically regulated in the snail body either by cellular compartmentalization or by complexation to specific metallothioneins [6]. Such processes of bioaccumulation in organisms may be associated with significant interactions between these trace metals and macro metallic elements such as K, Ca, Na and Mg. Thus, people who eat snails from estuarine or coastal areas from oil polluted soils are at risk of trace metal poisoning [8]. Very little information is known of metal levels in the African giant snail as consumed in the Southern part of Nigeria. This work was tailored towards assessing the levels of toxic trace metals in African giant snail commonly consumed by majority of populace in Southern Nigeria.

\section{Materials and Methods}

Study Area: Akwa Ibom is a leading petroleum producing state located in the Coastal Southern Nigeria, lying between latitudes $4^{\circ} 321$ and $5^{\circ} 331$ North and longitudes $7^{\circ} 251$ and $8^{\circ} 251$ East (Figure 1). Majority of the

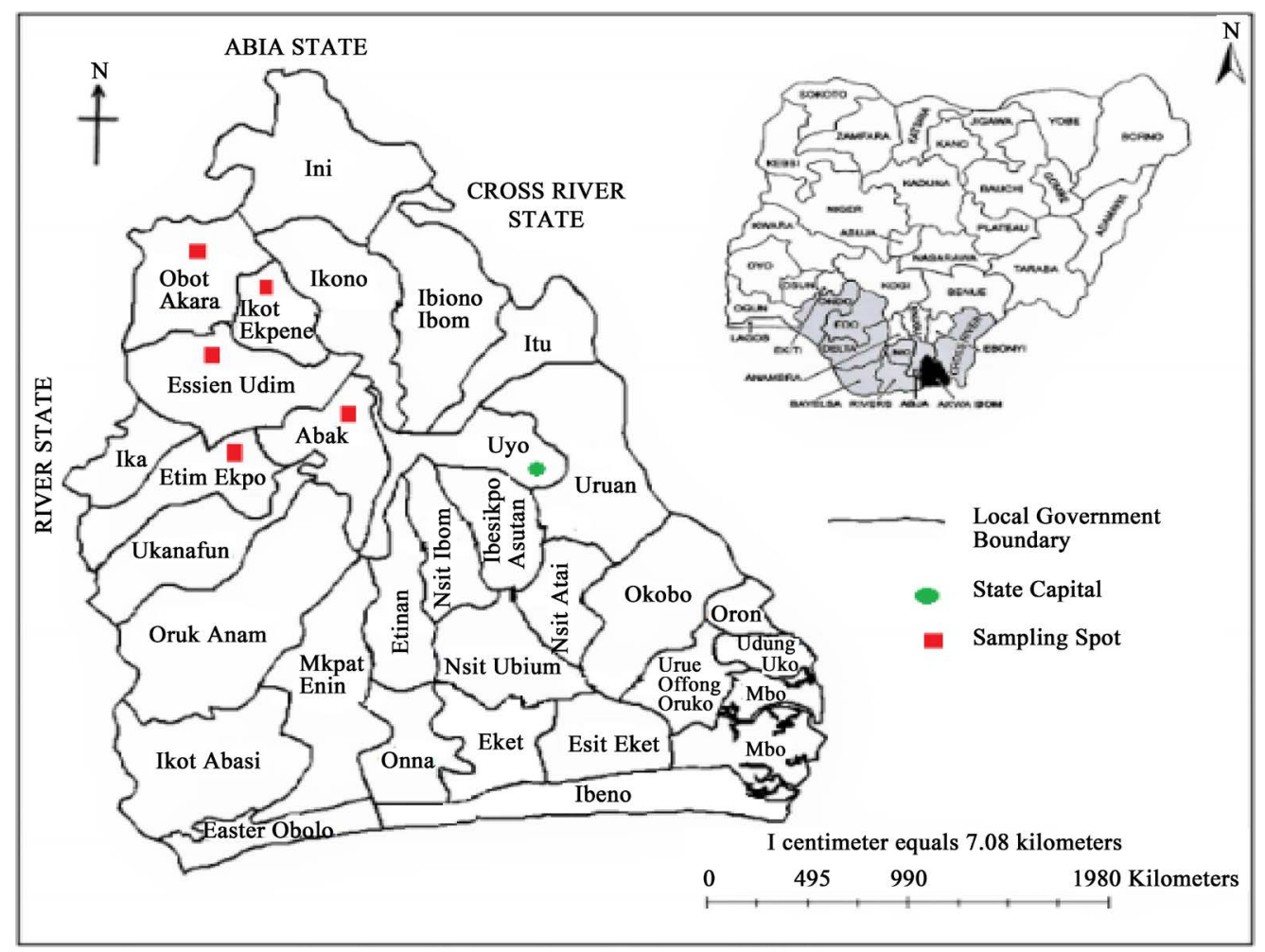

Figure 1. Map of Akwa Ibom State showing the location of the study areas [9]. 
populace are farmers, fishermen and craftsmen. Hence, the state is endowed with variety of food stuffs and protein sources especially aquatic foods.

Sampling: Five sampling stations were established (based on availability and consumption rate) from which the snail samples (A. achatina) were purchased from their various open markets in Akwa Ibom State. The names of those Local Government Areas in Akwa Ibom State are Abak, Obot Akara, Essien Udim, Ikot Ekpene and Etim Ekpo as indicated on the map of Akwa Ibom State shown in Figure 1. Ten (10) samples of A. achatina (mean length of $10.6 \pm 1.2 \mathrm{~cm}$ and mean weight of $87.8 \pm 27.6 \mathrm{~g}$ ) were collected from each of the five Local Government Areas making a total of 50 samples. The samples were packaged in polyethylene bags, labelled according to each sampling station and taken to laboratory for sample pre-treatment and analysis. A typical sample of A. achatina is illustrated in Figure 2.

The snail samples were sacrificed by striking with a wooden material on the shell carefully. The foot was then separated and washed with distilled de-ionized water, dried in an oven at the temperature of $105^{\circ} \mathrm{C}$ to constant weight. After drying, samples were ground to fine powder using porcelain mortar and pestle. The powdered samples were stored in $100 \mathrm{~mL}$ air tight bottles, ready for digestion.

Sample Digestion: Exactly $1.0 \mathrm{~g}$ of the dried powders sample was weighed accurately and transferred to a 50 $\mathrm{mL}$ beaker. A total of $10 \mathrm{~mL}$ of the digestion mixture in the ratio (1:2:2) perchloric, nitric and sulphuric acid was added into the sample and heated on a hot plate in a fume hood. The mixture was heated until a white fume was observed signifying complete digestion. The sample was allowed to cool and $20 \mathrm{~mL}$ of distilled de-ionized water was added to bring the metals into solution. The sample was allowed to cool to room temperature and filtered using What man filter into a $100 \mathrm{~mL}$ volumetric flask and made up to mark with distilled water and finally transferred to a $100 \mathrm{~mL}$ plastic bottle for atomic absorption spectroscopic (AAS) analysis. The AAS analysis was done in triplicates for each sample and calibration curves were obtained for the trace metals under investigations from their standard salts.

Statistical analysis: Microsoft Excel 2007 was used for graphical illustrations. Means were determined using SPSS version 16.0. One-way ANOVA (non-parametric test) statistical analysis was used to estimate differences and significance levels at $\mathrm{P}>0.05$.

\section{Results and Discussion}

The mean concentrations (mg/kg) of trace metal analysis were presented in bar charts as shown in Figures 3-7. Two out of six trace metals investigated remained within their permissible safe levels while four were significantly their above safe levels for human consumption. One of the trace metals (Hg) was below the detection limit in all the sampling areas.

As: In all the samples examined using AAS, As was detected in four samples in Abak, in Obot Akara one sample was detected. The level of As in the sampling area ranged from 0.21 to $0.81 \mathrm{mg} / \mathrm{kg}$ with mean concentration of $0.45 \pm 0.26 \mathrm{mg} / \mathrm{kg}$. In Essien Udim, Ikot Ekpene and Etim Ekpo Local Government areas, the levels of

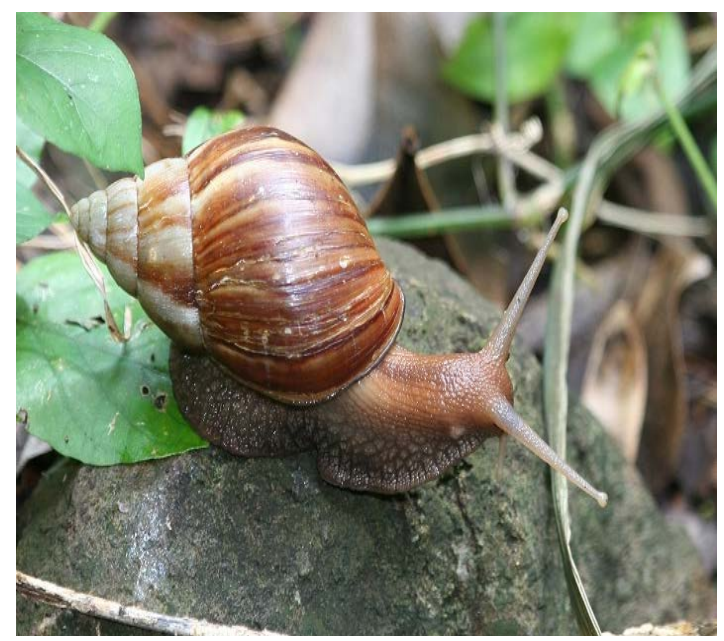

Figure 2. A typical African giant land snail (Achatina achatina). 
As were below the detection limit (Figure 3). The highest concentration of As was found in Abak to be 0.81 $\mathrm{mg} / \mathrm{kg}$. Adebayo-Tayo et al. [10] investigated As contents of freshwater snails from the creek in Niger Delta, Nigeria and values ranged from $0.04 \mathrm{mg} / \mathrm{kg}$ to $0.37 \mathrm{mg} / \mathrm{kg}$. Adedeji et al. [11] investigated heavy metals content in snail form Alaro River within Oluyole industrial area in Ibadan, Nigeria and the level of As recorded was 0.01 $\mathrm{mg} / \mathrm{kg}$. Nwoko et al. [12] reported the concentration of As in samples of snail for both shell and tissue. The results obtained were less than $0.50 \mathrm{mg} / \mathrm{kg}$ for the snail shell and tissue. The mean value reported in this work was within the range of other similar investigations.

Chronic exposure to As may cause serious impact on peripheral and central nervous system [13]. The levels of As recorded in Abak and Obot Akara were below maximum prescribed limits according to Food and Agriculture Organization/World Health Organization [14] recommended values for elements.

Cd: Cadmium levels in the snail samples from Abak was high and alarming, it ranged from $0.42 \mathrm{mg} / \mathrm{kg}$ to $2.80 \mathrm{mg} / \mathrm{kg}$ which were above the standard limit of $0.3 \mathrm{mg} / \mathrm{kg}$ [14]. The level at Obot Akara, Essien Udim, Ikot Ekpene and Etim Ekpo Local Government area were below the detection limit (Figure 4). Chukwujindu et al.

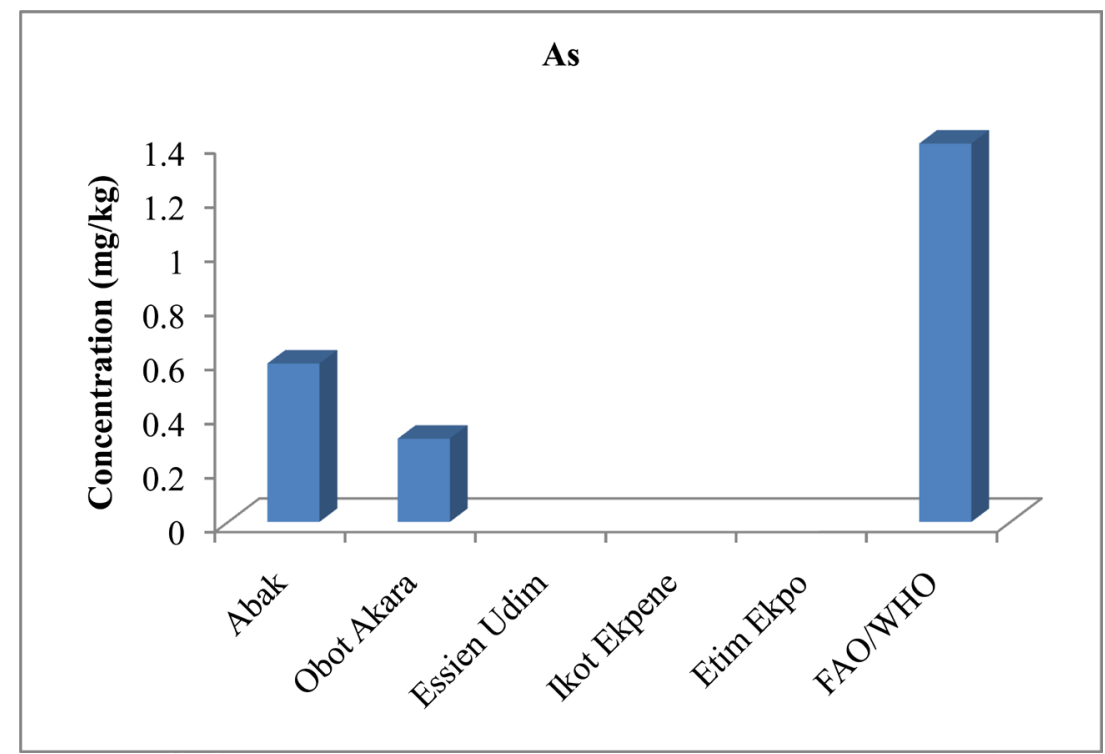

Figure 3. Mean concentrations ( $\mathrm{mg} / \mathrm{kg}$ ) of As in A. achatina samples in different LGA in Akwa Ibom State, Nigeria.

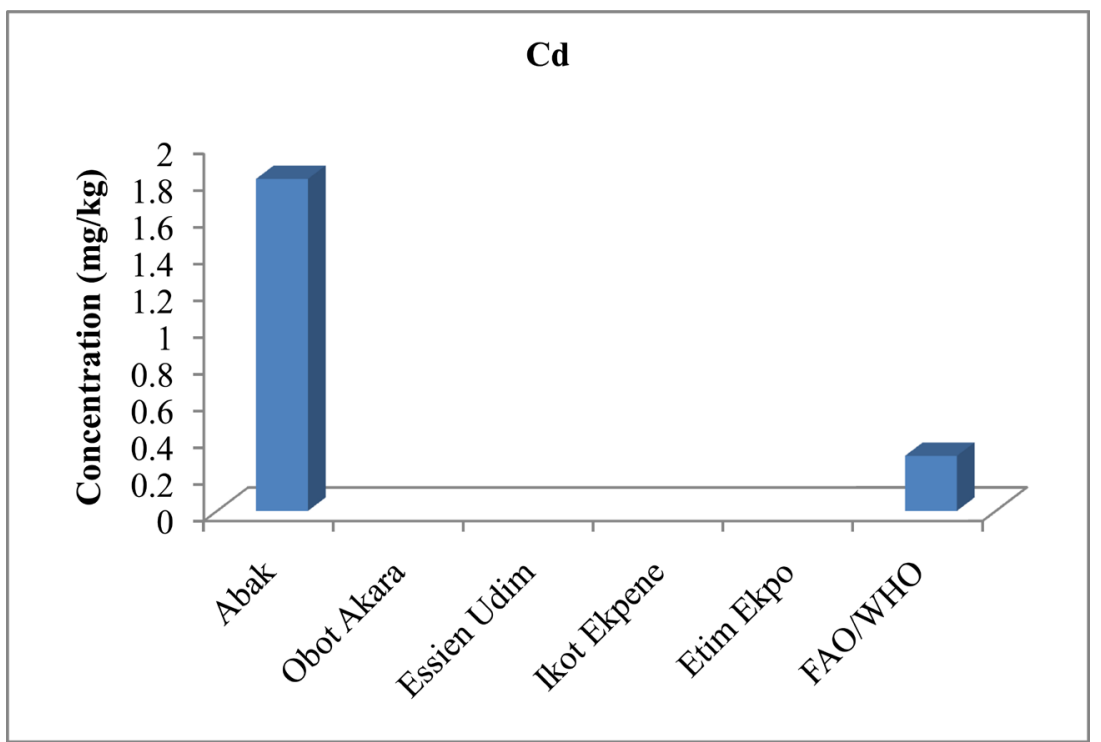

Figure 4. Mean concentrations (mg/kg) of Cd in A. achatina samples in different LGA in Akwa Ibom State, Nigeria. 
[15] reported $0.99 \mathrm{mg} / \mathrm{kg}$ to $3.28 \mathrm{mg} / \mathrm{kg}$ range of Cd in giant African snail (Archachatina marginata) from nine localities in southern Nigeria, which is greater than the amount detected in this work. Neeratanaphan et al. [16] working on genetic erosion in the freshwater snail (filopaludina martensi) reported the average concentrations of $\mathrm{Cd}$ found in the tissue of freshwater snails during the rainy season to be $0.10 \mu \mathrm{g} / \mathrm{g}$, in winter $0.06 \mu \mathrm{g} / \mathrm{g}$ and summer $0.07 \mu \mathrm{g} / \mathrm{g}$, respectively.

Adedeji et al., [11] recorded a concentration of $0.01 \mathrm{mg} / \mathrm{kg}$ Cd in snail from Alaro River within Oluyole industrial area in Ibadann Nigeria. Sivaperumal et al. [17] found Cd concentrations ranging from undetectable to $0.98 \mathrm{mg} / \mathrm{kg}$ in some mollusc species in India. The levels of $\mathrm{Cd}$ found in this study were higher than the range reported by those investigators, but lower than the $5.7 \mathrm{mg} / \mathrm{kg}$ cadmium reported for land snails collected near a highway in France [18]. Ayenimo et al. [19] reported Cd concentration to be $0.57 \mathrm{mg} / \mathrm{kg}$ in periwinkles samples (Tympanostomus fuscatus) bought from different major markets in Warri Township of Delta State, Nigeria. Eneji et al. [20] reported $0.93 \mathrm{mg} / \mathrm{kg}$ and $0.99 \mathrm{mg} / \mathrm{kg}$ in C. gariepinus and T. zilli from River Benue. Falusi and Olanipekun, [21] reported cadmium concentration in tropical crab from Aponwe, river Ado-Ekiti to be 0.07 $\mathrm{mg} / \mathrm{kg}$, less than that detected in this work. The level of Cd obtained may induce kidney dysfunction, skeletal damage and reproductive deficiency for those that consume snails [22]. The levels of Cd recorded in Abak were higher than the maximum prescribed limit as recommended by Codex Alimentarius Commission [14]. This high level of Cd might be due to anthropogenic sources which include industrial effluents, application of fertilizers and sewage sludge to farmland [23].

Cr: Chromium in trivalent state is an essential trace element that potentiates insulin action and thus influences carbohydrate, lipid and protein metabolism [24]. In this study, the level of $\mathrm{Cr}$ was found to be significantly higher $(\mathrm{P}<0.05)$. The level of $\mathrm{Cr}$ in all the sampling areas ranged from 40.8 to $857 \mathrm{mg} / \mathrm{kg}$ with mean concentration of $379 \pm 195 \mathrm{mg} / \mathrm{kg}$. The mean level $\mathrm{Cr}$ at each local government area was presented in Figure 5 . The highest mean concentration of chromium was recorded in Obot Akara Local Government area. Adedeji et al. [11] recorded a concentration of $0.08 \mathrm{mg} / \mathrm{kg} \mathrm{Cr}$ in snail form Alaro River within Oluyole industrial area in Ibadan, Nigeria.

Nwoko et al. [12] reported the concentration of $\mathrm{Cr}$ in samples of snail for both shell and tissue. The results obtained were less than $1.00 \mathrm{mg} / \mathrm{kg}$ and $1.00 \mathrm{mg} / \mathrm{kg}$ for shell and tissue, respectively. Ayenimo et al. [19] reported chromium concentration to be $13.6 \mathrm{mg} / \mathrm{kg}$ in periwinkles samples (Tympanostomus fuscatus) bought from different major markets in Warri Township of Delta State, Nigeria. Eneji et al. [20] reported $92.9 \mathrm{mg} / \mathrm{kg}$ of $\mathrm{Cr}$ in $T$. zilli and $88.5 \mathrm{mg} / \mathrm{kg}$ of $\mathrm{Cr}$ in C. gariepinus from river Benue. The level of $\mathrm{Cr}$ recorded in all the sampling stations were higher than the maximum prescribed limit as recommended by Codex Alimentarius Commission values for elements [14]. Excessive intake of this element has an adverse effect on human health as it is considered as carcinogenic in its +6 oxidation state.

Hg: Mercury is one of the most toxic elements among the studied trace metals and exposure to moderate level of this element could permanently damage the brain, kidneys and developing foetus [14]. The levels of Hg in African giant snail investigated were below detection limit in all the five sampling stations examined. Piansiri and Pachanee [25] reported the concentrations of $\mathrm{Hg}$ found in the snail tissues and water after 96 hours of exposure and the mean concentrations of mercury in the experimental water after 96 hour was $0.12 \pm 0.00 \mathrm{mg} / \mathrm{L}$. Ekpo et al. [26] reported Hg concentrations in Metacembelus Iconnbergii, Clarias lazera, Citarinus cithanus, Tilapia Zilli and Erpetoicithy from Ikpo River in Benin City, Nigeria to be $0.004 \mathrm{mg} / \mathrm{kg}, 0.003 \mathrm{mg} / \mathrm{kg}, 0.003 \mathrm{mg} / \mathrm{kg}$, $0.00 \mathrm{mg} / \mathrm{kg}$ and $0.002 \mathrm{mg} / \mathrm{kg}$, respectively. Alinnor and Obiji [27] work on Nworier river, reported Hg level of mean concentration in Liza grandisaquamis and Sphyraena Sphyraena to be $0.01 \mathrm{mg} / \mathrm{kg}$ and $0.01 \mathrm{mg} / \mathrm{kg}$, respectively. According to Codex Alimentarius Commission, the maximum Hg level permitted limit is $0.5 \mathrm{mg} / \mathrm{kg}$ [14].

Pb: Lead is toxic to humans, with the most deleterious effects on the hemopoietic, nervous, reproductive systems and the urinary tract. It has been documented that $\mathrm{Pb}$ causes damage to human kidneys and liver [17]. Food and Agriculture Organization/World Health Organization set maximum permitted level for $\mathrm{Pb}$ to be $1.5 \mathrm{mg} / \mathrm{kg}$ [14]. In this research, the concentration of lead analyzed in Obot Akara, Essien Udim, Ikot Ekpene and Etim Ekpo were below detection limit except in Abak where the $\mathrm{Pb}$ concentration was observed to be $1.91 \mathrm{mg} / \mathrm{kg}$ (Figure 6). Viard et al., [18] reported $21.3 \mathrm{mg} / \mathrm{kg} \mathrm{Pb}$ in A. achatina collected near a highway in France. Aboho et al. [28] investigated $\mathrm{Pb}$ contents of viscera and shells of A. achatina to be $0.43 \mathrm{mg} / \mathrm{kg}$ to $0.79 \mathrm{mg} / \mathrm{kg}$, in Makurdi Metropolis. Chukwujindu et al. [15] reported $0.77 \mathrm{mg} / \mathrm{kg}$ to $7.51 \mathrm{mg} / \mathrm{kg}$ range of $\mathrm{Pb}$ in giant African land snail (Archachatina marginata) from nine localities in southern Nigeria which is greater than the level detected 


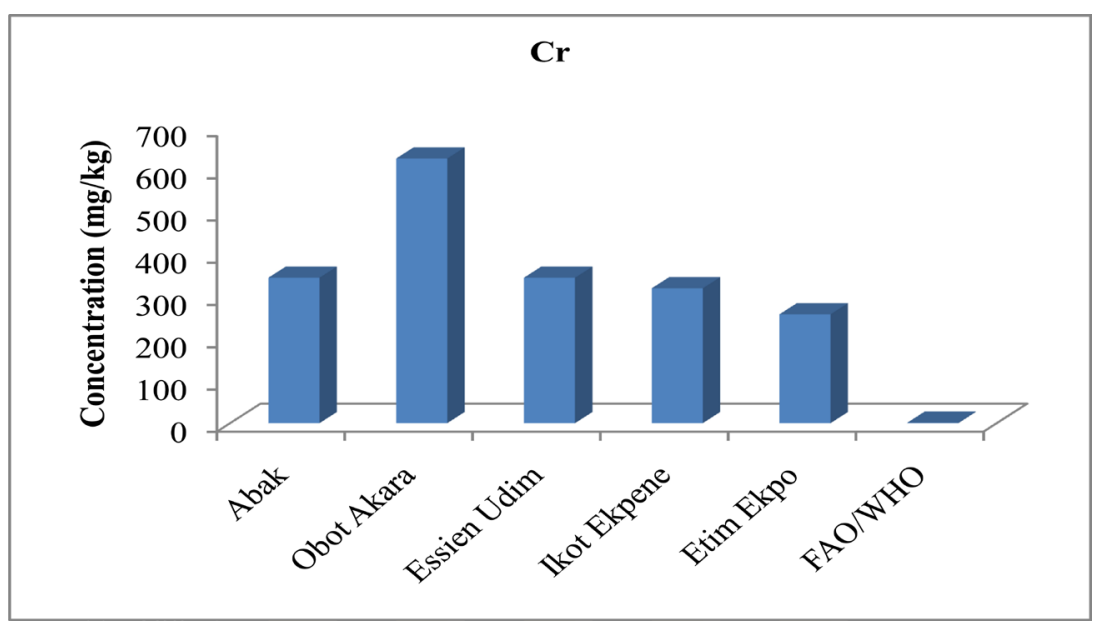

Figure 5. Mean concentrations (mg/kg) of $\mathrm{Cr}$ in A. achatina samples in different LGA in Akwa Ibom State, Nigeria.

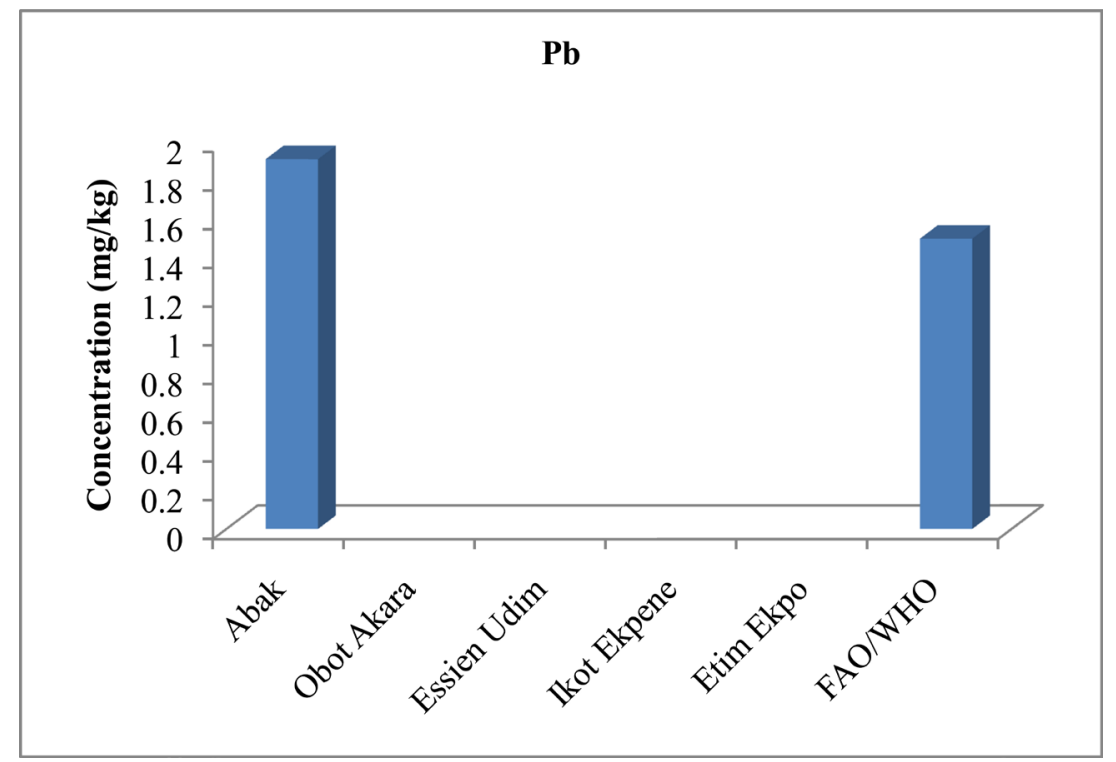

Figure 6. Mean concentrations (mg/kg) of $\mathrm{Pb}$ in A. achatina samples in different LGA in Akwa Ibom State, Nigeria.

in this work. Altu and Nihal [29] recorded $0.52 \mathrm{mg} / \mathrm{kg}$ to $1.25 \mathrm{mg} / \mathrm{kg}$ ranged concentration of Pb in sea snails (Rapana venosa) from the Northern Marmara Sea, Turkey. Neeratanaphan et al. [16] working on genetic erosion in the freshwater snail Filopaludina martensi reported the average concentrations of Pb found in the tissue of freshwater snails during the rainy season to be $0.01 \mu \mathrm{g} / \mathrm{g}$, in winter to be $0.00 \mu \mathrm{g} / \mathrm{g}$ and summer to be $0.01 \mu \mathrm{g} / \mathrm{g}$, respectively.

The higher concentration of $\mathrm{Pb}$ was measured in Abak which was higher than the maximum prescribed limit as recommended by Codex Alimentarius Commission [14] recommended values for elements. The main sources of $\mathrm{Pb}$ pollution are automobile exhaust gases and untreated industrial waste which finds its way to irrigation channels, thus polluting fodder through soil [30].

Se: The level of Se in the sampling area ranged from 24.8 to $72.4 \mathrm{mg} / \mathrm{kg}$ with mean concentration of $51.6 \pm$ $31.3 \mathrm{mg} / \mathrm{kg}$ (See Figure 7). Adrian and Nadezhda [31] reported Se contents of land snails ranged from 130 $\mu \mathrm{g} / \mathrm{kg}$ to $423 \mu \mathrm{g} / \mathrm{kg}$ in Helix pomatia from Bendery, Moldovian Republic.

Olabanji and Oluyemi [32] reported Se ranged in T. zillii fillet between $0.80 \mu \mathrm{g} / \mathrm{g}$ to $1.20 \mu \mathrm{g} / \mathrm{g}$ with mean concentration of $0.97 \pm 0.061 \mu \mathrm{g} / \mathrm{g}$ and in $M$. rume fillet, it ranged between $0.60 \mu \mathrm{g} / \mathrm{g}$ with mean concentration of $0.73 \pm 0.10 \mu \mathrm{g} / \mathrm{g}$. The level of Se recorded in Abak, Obot Akara, Essiem Udim, Ikot Ekpene and Etim Ekpo were all higher than the maximum prescribed limit as recommended by Codex Alimentarius Commission [14]. 


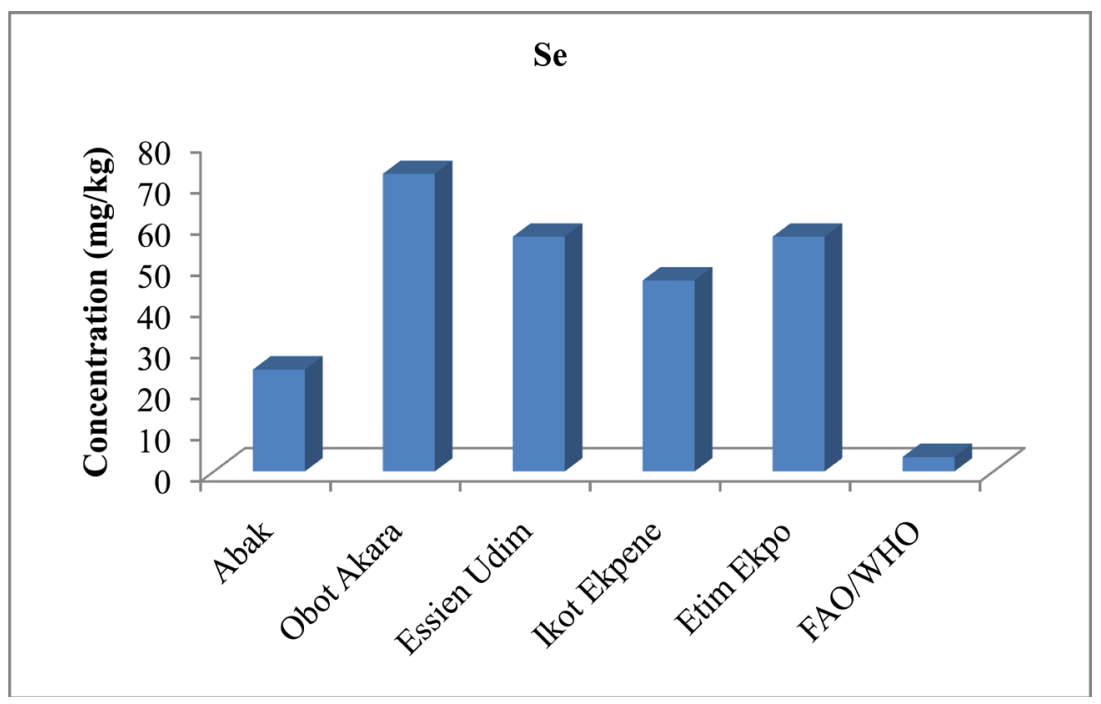

Figure 7. Mean concentrations (mg/kg) of Se in A. achatina samples in different LGA in Akwa Ibom State, Nigeria.

In this study, the level of Se was found to be significantly lower $(P>0.05)$ in Se content determined. Excess intake of Se can be toxic and symptoms that manifest in selenosis include a garlicky odour of the breath, hair loss, nausea, diarrhoea, fatigue, changes in fingernails and toenails.

\section{Conclusion}

The present study revealed that African giant land snail samples obtained from the study area of Akwa Ibom State contained significantly high levels of trace metals that exceed the maximum prescribed limits for elements [14]. Although snails are nutritionally richer in protein, the high concentrations of trace metals observed in this work can be related to the anthropogenic activities taking place in these areas. Even though As and Hg fell within their permissible safe levels for human consumption, $\mathrm{Cd}, \mathrm{Cr}, \mathrm{Pb}$ and Se were significantly above their safe levels for human consumption.

\section{Acknowledgements}

Our appreciation goes to Mr. and Mrs Joe A. Udoh, Mr. Ugbidye Shappera and Mr. Peter Onuwa for their useful advice and assistance during sampling. We also appreciate the staff of Golden Years Limited Port Harcourt for their technical assistance during the atomic absorption spectrophotometer (AAS) analysis.

\section{References}

[1] Gaur, A. and Adholeya, A. (2004) Prospects of Arbuscular Mycorrhizal Fungi in Phytoremediation of Heavy Metal Contaminated Soils. Current Science, 86, 528-534.

[2] Malik, A. (2004) Metal Bioremediation through Growing Cells. Chemosphere, 30, 261-278. http://dx.doi.org/10.1016/j.envint.2003.08.001

[3] Manohar, S., Jadia, C.D. and Fulekar, M.H. (2006) Impact of Ganesh Idol Immersion Onwater Quality. Indian Journal of Environmental Protection, 27, 216-220.

[4] Nica, D.V., Bura, M., Gergen, I., Harmanescu, M. and Bordean, D.M. (2012) Bioaccumulative and Conchological Assessment of Heavy Metal Transfer in a Soil-Plant-Snail Food Chain. Chemistry Central Journal, 6, 55-60. http://dx.doi.org/10.1186/1752-153X-6-55

[5] Johnston, R. (1990) Marine Pollution. Academic Press, London, 12-15.

[6] Dallinger, R., Berger, B., Gruber, C. and Sturzenbaum, S. (2000) Metallothioneins in Terrestrial Invertebrates: Structural Aspects, Biological Significance, and Implications for Their Use as Biomarkers. Cell and Molecular Biology, 46, 331-346.

[7] Gomot de Vaufleury, A., Coeurdassier, M., Pandard, P., Scheifler, R., Lovy, C., Crini, N. and Badot, P.M. (2006) How Terrestrial Snails Can Be Used in Risk Assessment of Soils. Environmental Toxicology and Chemistry, 25, 797-806. 
http://dx.doi.org/10.1897/04-560R.1

[8] Mahmood, S.N., Naeom, S., Khan, F.A. and Qadri, R.B. (1995) Heavy Metals in 15 Species of Pakistan Commercial Fish. Tropical Science, 35, 389-394.

[9] Ite, A.E., Udousoro, I.I. and Ibok, U.J. (2014) Distribution of Some Atmospheric Heavy Metals in Lichen and Moss Samples Collected from Eket and Ibeno Local Government Areas of Akwa Ibom State, Nigeria. American Journal of Environmental Protection, 2, 22-31. http://dx.doi.org/10.12691/env-2-1-5

[10] Adebayo-Tayo, B.C., Onilude, A.A. and Etuk, F.I. (2011) Studies on Microbiological, Proximate Mineral and Heavy Metal Composition of Freshwater Snails from Niger Delta Creek in Nigeria. Assumption University Journal of Technology, 14, 290-298.

[11] Adedeji, O.B., Adeyemo, O.K. and Oyedele, M.O. (2011) Heavy Metals in Snail and Water Samples from Alaro River in Oluyole Industrial Area of Ibadan Southwestern Nigeria. Journal of Applies Sciences in Environmental Sanitation, 6, 115-121.

[12] Nwoko, C.I.A., Ukiwe, L.N. and Oshoakpeme, G.S. (2014) Heavy Metals Concentrations in the Shell and Tissue of Periwinkle (Tympanotonus fuscatus) and Giant Land Snail (Achatina fulica) in Soku Community of Niger Delta, Nigeria. Journal of Advances in Chemistry, 10, 3.

[13] Jarup, L. (2003) Hazards of Heavy Metal Contamination. British Medical Bulletin, 68, 167-182. http://dx.doi.org/10.1093/bmb/ldg032

[14] FAO/WHO (Food and Agriculture Organization/World Health Organization) (1984) List of Maximum Levels Recommended for Contaminants by the Joint FAO/WHO Codex Alimentarius Commission. Second Series. CAC/FAL, Rome, 3, 1-8.

[15] Chukwujindu, M.A.I., Francis, O.A., Godwin E.N. and Osa, E. (2008) Heavy Metal Content in the African Giant Snail Archachatina marginata (Swainson, 1821) (Gastropoda: Pulmonata: Achatinidae) in Southern Nigeria. Folia Malacologica, 16, 31-34.

[16] Neeratanaphan, L., Sudmoon, R. and Chaveerach, R. (2014) Genetic Erosion in the Freshwater Snail Filopaludina martensi Is Affected by Lead and Cadmium. Applied Ecology and Environmental Research, 12, 991-1001. http://dx.doi.org/10.15666/aeer/1204_9911001

[17] Sivaperumal, P.S., Ankar T.V. and Viswanathan Nair, P.G. (2007) Heavy Metal Concentrations in Fish, Shellfish and Fish Products from Internal Markets of India Vis-a-Vis International Standard. Food Chemistry, 102, 612-630. http://dx.doi.org/10.1016/j.foodchem.2006.05.041

[18] Viard, B., Pihan, F., Promeyrat, S. and Pihan, J.C. (2004) Integrated Assessment of Heavy Metals (Pb, Zn, Cu) Highway Pollution; Bioaccumulation in Soil, Graminaceae and Land Snails. Chemosphere, 55, 1349-1359. http://dx.doi.org/10.1016/j.chemosphere.2004.01.003

[19] Ayenimo, J.G., Adeeyinwo, C.E., Amoo, I.A. and Odukudu, F.B. (2005) A Preliminary Investigatio of Heavy Metals in Periwinkles from Warri River, Nigeria. Journal of Applied Sciences, 5, 813-815.

[20] Eneji, I.S., Sha’ Ato, R. and Annune, P.A. (2011) Bioaccumulationof Heavy Metals in Fish (Tilapia zilli and Clarias gariepinus) Organs from River Benue, North-Central Nigeria. Pakistan Journal of Analytical and Environmental Chemistry, 12, 25-31.

[21] Falusi, B.A. and Olanipekun, E.O. (2007) Bio Concentration Factors of Heavy Metals in Tropical Crab (Carcinus sp.) from River Aponwe, Ado-Ekiti, Nigeria. Journal of Applied Science and Environmental Management, 11, 51-54.

[22] Agusa, T., Kunito, T., Yasunaga, G., Iwata, H., Subramanian, A., Ismail, A. and Tanabe, A. (2005) Concentrations of Trace Elements in Marine fish and Its Risk Assessment in Malaysia. Marine Pollution Bulletin, 51, 896-911. http://dx.doi.org/10.1016/j.marpolbul.2005.06.007

[23] ATSDR (Agency for Toxic Substance and Disease Registry) (2012) Toxicological Profile for Cadmium (Public Health Statement). US Department of Health and Human Services, Public Health Services, Centers for Disease Control, Atlanta, 1-10.

[24] Duran, A., Tuzen, M. and Soylak, M. (2008) Trace Element Levels in Some Dried Fruit Samples from Turkey. International Journal of Food Sciences and Nutrition, 59, 581-589. http://dx.doi.org/10.1080/13561820701507910

[25] Piansiri, P. and Pachanee, B. (2008) Comparative Toxicity of Mercury and Cadmium to the Juvenile Freshwater Snail (Filopaludina martensi martensi). Science Asia, 34, 367-37. http://dx.doi.org/10.2306/scienceasia1513-1874.2008.34.367

[26] Ekpo, K.E., Asia, I.O., Amago, K.O. and Jegede, D.A. (2008) Determination of Lead, Cadmium and Mercury in Surrounding Water and Organs of Some Species of Fish from Ikpoba River in Benin City, Nigeria. International Journal of Physical Sciences, 3, 289-292.

[27] Alinnor, I.J. and Obiji, I.A. (2010) Assessment of Trace Metal Composition in Fish Samples from Nworie River. Paki- 
stan Journal of Nutrition, 9, 81-85. http://dx.doi.org/10.3923/pjn.2010.81.85

[28] Aboho, S.Y., Anhwange, B.A. and Ber, G.A. (2009) Screening of Achatina achatina and Pila ovata for Trace Metals in Makurdi Metropolis. Pakistan Journal of Nutrition, 8, 1170-1171. http://dx.doi.org/10.3923/pjn.2009.1170.1171

[29] Altu, G. and Nihal, G. (2002) Determination of the Levels of Indicator Bacteria, Salmonella spp. and Heavy Metals in Sea Snails (Rapana venosa) from the Northern Marmara Sea, Turkey. Turkish Journal of Fisheries and Aquatic Sciences, 2, 141-144.

[30] Mariam, I., Iqbal, S. and Nagra, S.A. (2004) Distribution of Some Trace and Macrominerals in Beef, Mutton and Poultry. International Journal of Agriculture and Biology, 6, 816-820.

[31] Adrian, T.W. and Nadezhda, G. (2009) Investigation upon the Edible Snail's Potential as Source of Selenium for Human Health and Nutrition Observing Its Food Chemical Contaminant Risk Factor with Heavy Metals. Bulletin of University of Agricultural Sciences and Veterinary Medicine, 66, 495.

[32] Olabanji, I.O. and Oluyemi, E.A. (2014) Preliminary Assessment of Heavy Metal Pollution of Opa Reservoir, Ile-Ife, Southwest Nigeria Using Mormyrus rume and Tilapia zillii. Ife Journal of Science, 16, 1-8. 